- les méthodes de séchage conduisent à des résultats analogues, contrairement à une expérience précédente laissant entenđre que le séchage en deux temps, notamment, préservait mieux l'intégrité du grain de maïs ;

- les températures de séchage, allant de 90 à $150^{\circ} \mathrm{C}$ pour les deux méthodes à l'essai, sont également sans influence sur les résultats des essais.

\author{
SUMMARY \\ FEEDING VALUE OF MAIZE SUBJECTED TO DIFFERENT \\ DRYING TREATMENTS : TWO-STAGES DRYING OR DRYING \\ FOLLOWED BY DEI,AYED SLOW COOLING
}

In order to increase the reception rate of dryers during the period of harvesting, it is possible either to dry the maize till about $20 \mathrm{p}$. Ioo humidity, followed by storage without cooling and drying in a bin (delayed cooling), or to dry the maize provisionally till $25 \mathrm{p}$. Ioo humidity, followed by ventilation until the definitive drying (two-stages drying).

Two similar experiments (one per drying method) dealing with feeding of growing-finishing pigs from 25 to $103 \mathrm{~kg}$ live weight were made. The purpose was to compare these two methods with the classical one-stage drying at $90^{\circ} \mathrm{C}$ and in the case of two-stages drying, comparison was also made with drying at $4 \mathrm{O}^{\circ} \mathrm{C}$ according to the "herring-bone " system. The experiments did not show any difference between the two main factors of the trial :

- the drying methods gave analogous results contrarily to a previous trial, which indicated that two-stages drying, in particular, resulted in a better preservation of the integrity of the kernel ;

- the drying temperatures $\left(90\right.$ to $150^{\circ} \mathrm{C}$ ) of the two methods studied did not affect the results of the experiments.

\title{
ESSAI D'UTILISATION DE FORTES PROPORTIONS DE MÉlaSSE DE CANNE A SUCRE DANS LES RATIONS DU POHCELET SEVRÉ A 5 SEMAINES ET DU PORC EN CROISSANCE-FINITION
}

\author{
J. LE DIVIDICH, B. SEVE, I. CANOPE et H. KEMPF \\ Station de Recherches sur l'Élevage des Porcs, \\ Centre national de Recherches zootechniques, I. N. R. A., \\ 78350 Jouy en Josas \\ Station de Recherches zootechniques, \\ Centre de Recherches agronomiques des Antilles-Guyane, I. N.R. A., \\ Domaine Duclos, 97170 Petit Bourg (Guadeloupe)
}

\section{RÉSUMÉ}

Trois essais ont été réalisés afin de connaître :

$I^{\circ}$ L'effet d'une incorporation importante (o à $40 \mathrm{p}$. 10o) de mélasse finale de canne dans les régimes de sevrage sur les performances du porcelet entre 5 et 9 semaines d’âge. 
$2^{\circ} \mathrm{La}$ valeur en énergie digestible de la mélasse pour le porc de 30 à $40 \mathrm{~kg}$.

$3^{\circ}$ L'effet des régimes riches en mélasse (30 à $40 \mathrm{p}$. Ioo) associée à divers taux de bagasse et de sucre brut sur les performances du porc entre 25 et $95 \mathrm{~kg}$.

De l'ensemble des résultats, il ressort les faits suivants :

Essai 1. Le porcelet tolère $20 \mathrm{p}$. Ioo de mélasse dans sa ration de sevrage, une proportion plus forte (4o p. Ioo) entraîne une mortalité importante $(25 \mathrm{p}$. Ioo).

Les performances de croissance, l'efficacité alimentaire et la digestibilité apparente des principaux éléments de la ration (matière sèche, énergie, azote) diminuent significativement avec l'augmentation du taux de mélasse. L'humidité de fèces augmente également avec le pourcentage de mélasse.

Essai 2. La valeur en énergie digestible de la mélasse estimée par "la méthode par addition " est de $2500 \mathrm{kcal} / \mathrm{kg}$.

Essai 3. Les performances des porcs recevant des régimes riches en mélasse (30 à 40 p. 100) du régime) sont inférieures à celles des animaux recevant le régime témoin. Elles diminuent iorsque le pourcentage de mélasse augmente.

L'addition de proportion croissante de bagasse au régime $(0,6$ et $\mathrm{I} 2 \mathrm{p}$. Ioo) provoque une diminution de la croissance journalière des animaux et une augmentation de l'indice de consommation : elle entraîne par contre une amélioration de la qualité des carcasses (épaisseur du lard dorsal).

L'humidité des fèces est toujours élevée (80 p. Ioo environ), elle tend à diminuer avec l'incorporation de bagasse.

\section{SUMMARY}

\section{UTILIZATION OF HIGH PROPORTIONS OF SUGAR CAN MOLASSES IN THE RATIONS OF PIGLETS WEANED AT 5 WEEKS AND IN THOSE OF GROWING-FINISHING PIGS}

Three trials were made in order to determine :

$I^{0}$ The effect of a large incorporation (o to $40 \mathrm{p}$. Ioo) of sugar can molasses into weaning diets on the performances of piglets between 5 and 9 weeks of age.

$2^{0}$ Digestible energy value of these molasses for the pig between 30 and $40 \mathrm{~kg}$.

$3^{\circ}$ The effects of diets with high molasses contents ( 30 to $40 \mathrm{p}$. I00) associated with various levels of bagasse and crude sugar on the fattening performances of pigs between 25 and $95 \mathrm{~kg}$.

The results show the following facts.

Trial 1. The piglets tolerated 20 p. Ioo of molasses in the weaning diet, a greater proportion (40 p. I0o) resulted in high mortality (25 p. I00).

The growth performances, feed efficiency and apparent digestibility of the main components of the ration (dry matter, energy, protein) significantly decreased when the content of molasses increased. The humidity of faeces also increased in the percentage of molasses.

Trial 2 . The digestible energy value of the molasses estimated by "the addition method " represented $2300 \mathrm{kcal} / \mathrm{kg}$.

Trial 3. The performances of the pigs receiving diets with high contents of molasses (3o to $40 \mathrm{p}$. Ioo of the diet) were lower than those of the animals fed the control diet. They decreased when the percentage of molasses increased. 
The addition to the diet of increasing proportions of bagasse (o, 6 and 12 p. roo) caused a decrease in the daily growth of the animals and an increase of the feed conversion ratio; on the other hand, it led to improvement of the carcass quality (backfat thickness).

The humidity of faeces was always high (about $80 \mathrm{p}$. I0o), and tended to decrease with the incorporation of bagasse. 